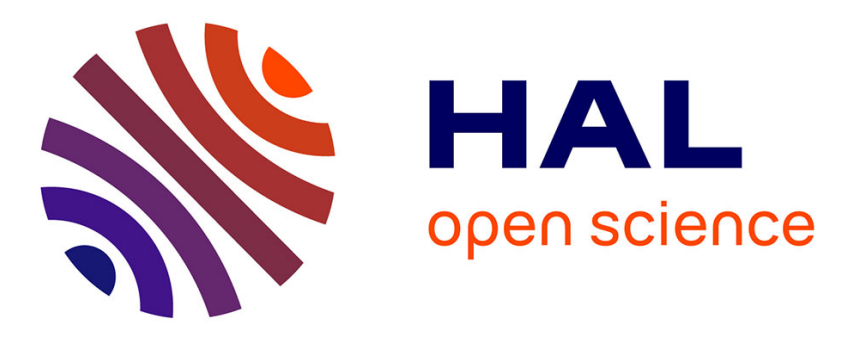

\title{
Branched-chain fatty acids, increased in tears of blepharitis patients, are not toxic for conjunctival cells
}

Corinne Joffre, Maxime Souchier, Laurent Leclere, Bénédicte Buteau, Stéphane Grégoire, Gérard Lizard, Thomas Montange, Niyazi Acar, Alain M Bron, Catherine P Creuzot-Garcher, et al.

\section{To cite this version:}

Corinne Joffre, Maxime Souchier, Laurent Leclere, Bénédicte Buteau, Stéphane Grégoire, et al.. Branched-chain fatty acids, increased in tears of blepharitis patients, are not toxic for conjunctival cells. British Journal of Ophthalmology, 2009, 93 (10), pp.1391-n/a. 10.1136/bjo.2008.156356 . hal-00477844

\section{HAL Id: hal-00477844 \\ https://hal.science/hal-00477844}

Submitted on 30 Apr 2010

HAL is a multi-disciplinary open access archive for the deposit and dissemination of scientific research documents, whether they are published or not. The documents may come from teaching and research institutions in France or abroad, or from public or private research centers.
L'archive ouverte pluridisciplinaire HAL, est destinée au dépôt et à la diffusion de documents scientifiques de niveau recherche, publiés ou non, émanant des établissements d'enseignement et de recherche français ou étrangers, des laboratoires publics ou privés. 


\section{Branched-chain fatty acids, increased in tears of blepharitis patients, are not toxic for conjunctival cells}

Corinne Joffre ${ }^{\mathrm{a}^{*}}$, Maxime Souchier ${ }^{\mathrm{b}}$, Laurent Leclere $^{\mathrm{a}}$, Bénédicte Buteau ${ }^{\mathrm{a}}$, Stéphane Grégoire $^{\mathrm{a}}$, Gérard Lizard ${ }^{\mathrm{c}}$, Thomas Montange ${ }^{\mathrm{c}}$, Niyazi Acar ${ }^{\mathrm{a}}$, Alain Bron ${ }^{\mathrm{ab}}$, Catherine Creuzot-Garcher ${ }^{\mathrm{ab}}$, Yolanda Diebold ${ }^{\mathrm{d}}$, Lionel Bretillon ${ }^{\mathrm{a}}$

${ }^{a}$ Eye and Nutrition Research Group, UMR 1129 FLAVIC, INRA, Dijon, France.

${ }^{\mathrm{b}}$ Department of Ophthalmology, University Hospital, Dijon, France.

${ }^{\mathrm{c}}$ INSERM U498, Dijon, France.

d University Institute of Applied Ophthalmobiology (IOBA), University of Valladolid, Valladolid, Spain.

* corresponding author: Corinne Joffre, present address : PsyNuGen, Université Bordeaux 2, INRA UMR1286, CNRS UMR5226, 146 rue Léo Saignat, 33076 Bordeaux Cedex, France. Phone: $\quad+33 .(0) 5.57 .57 .12 .48, \quad$ Fax: $\quad+33 .(0) 5.57 .57 .12 .27, \quad$ Email: corinne.joffre@bordeaux.inra.fr

Keywords: branched-chain fatty acids, tears, blepharitis, conjunctiva.

Word count: 2499

The Corresponding Author has the right to grant on behalf of all authors and does grant on behalf of all authors, an exclusive license (or nonexclusive for government employees) on a worldwide basis to the BMJ Publishing Group Ltd to permit this article (if accepted) to be published in BJO and any other BMJPGL products and sublicenses such use and exploit all subsidiary rights, as set out in our license.

Competing Interest: None declared. 


\section{Abstract}

Purpose: The composition of the meibum of blepharitis patients is characterised by increased levels of branched-chain fatty acids (BCFAs) that return to normal values in patients treated with cyclins and lid hygiene. The aim of this study was to determine if BCFAs had toxic effects on conjunctival cells related to the disease.

Methods: Chang and IOBA-NHC conjunctival human cells were treated with BCFAs (isoC16, and isoC20) or palmitic acid as a control for $4 \mathrm{~h}$ or $24 \mathrm{~h}$ at $50 \mu \mathrm{M}$ or $100 \mu \mathrm{M}$. Morphological and functional changes were investigated by measuring mitochondrial dehydrogenase activity, cell permeability, mitochondrial depolarisation, chromatin condensation, IL-1 $\beta$ and reactive oxygen species production.

Results: None of the fatty acids modified the parameters of cytotoxicity in conjunctival cells in Chang or IOBA-NHC cell lines. Only the mitochondrial dehydrogenase activity was significantly decreased in relation to the isoC20 concentration increase.

Conclusions: The increase in BCFAs in the tears of blepharitis patients does not consistently participate in the conjunctival cell changes throughout the course of the disease. Instead, it is likely an adaptive response of the ocular surface to the lack of tears, possibly increasing meibum fluidity, thus enhancing lacrimal film stability. 


\section{INTRODUCTION}

Blepharitis is a very frequent cause for consultation in ophthalmology [1] because of the procession of symptoms that are generated. [2] In previous papers, we showed that posterior blepharitis associated with meibomian gland dysfunction (MGD) leads to changes in meibomian lipids, particularly to a significant decrease in saturated fatty acids and a significant increase in the proportion of branched-chain fatty acids (BCFAs) [3], which lowered after minocycline treatment and lid hygiene. [4] These modifications should involve changes in the quality and therefore in the function of the lipidic phase of the tear film, whose most important role is to avoid evaporation of tears from the ocular surface. [5] Since the tear film is in permanent contact with conjunctival cells, we aimed to determine if an increase in BCFAs was toxic for conjunctival cells or if instead it was an adaptive response of the ocular surface to the lack of tears. On one hand, BCFAs may have toxic effects on conjunctival cells, as other BCFAs such as phytanic acid and methyltetradecanoic acid affect astrocytes, smooth muscle cells and breast cancer cells. [6, 7] On the other hand, as observed in vitro [8], BCFAs may improve tear stability, counterbalancing the lack of tears in blepharitis patients by facilitating the spread of the tear film on the ocular surface.

To clarify this point, we evaluated the cytotoxicity of BCFAs on cultured conjunctival cells by assessing mitochondrial dysfunction, inflammation and apoptosis, comparing them with palmitic acid (C16), a straight-chain fatty acid used as a control. We studied the effect of two of the main BCFAs present in tear lipids that were significantly increased in blepharitis: isoC16 and isoC20. [3] We compared the results in two cell lines: the Wong-Kilbourne derivative of Chang conjunctival cell lines, which has been widely used for toxicological in vitro studies, and the IOBA-NHC cell line, which showed a toxicological profile comparable to the Chang cells [9], to lessen the impact of the presence of HeLa marker chromosomes in the Chang cells. 


\section{MATERIALS AND METHODS}

\section{Cells}

Two conjunctival cell lines of human origin were cultured in standard conditions $\left(5 \% \mathrm{CO}_{2}\right.$, $95 \% \mathrm{O}_{2}, 37^{\circ} \mathrm{C}$ ). Chang cells (Wong-Kilbourne derivative of Chang conjunctiva, clone 1-5c-4, ATCC CCL-7) were cultured in Eagle's minimal essential medium (DMEM) with a high glucose concentration (4.5 g/L) $\quad\left(\right.$ Gibco $^{\mathrm{TM}}$, Invitrogen, Bioblock, Illkirch, France) supplemented with $10 \%$ fetal calf serum (FCS) (Eurobio, Courtaboeuf, France), $25 \mathrm{mM}$ HEPES $\left(\mathrm{Gibco}^{\mathrm{TM}}\right), 20 \mu \mathrm{g} / \mathrm{mL}$ gentamicine $\left(\mathrm{Gibco}^{\mathrm{TM}}\right)$. A second human conjunctival cell line spontaneously arising from a primary culture of human conjunctival epithelium (IOBA-NHC) was cultured in DMEM/F-12 (1:1) $\left(\mathrm{Gibco}^{\mathrm{TM}}\right)$ supplemented with $2 \mathrm{ng} / \mathrm{mL}$ epidermal growth factor (EGF) (AbCys, Paris, France), $1 \mu \mathrm{g} / \mathrm{mL}$ bovine pancreas insulin (Sigma-Aldrich, Saint Quentin Fallavier, France), $0.1 \mu \mathrm{g} / \mathrm{mL}$ cholera toxin (Sigma-Aldrich), $5 \mu \mathrm{g} / \mathrm{mL}$ hydrocortisone (Sigma-Aldrich), 10\% FCS, and $20 \mu \mathrm{g} / \mathrm{mL}$ gentamicin $\left(\mathrm{Gibco}^{\mathrm{TM}}\right)$. Cells from passages 9 and 10 (following ATCC initial passage 65 or following the provision of IOBANHC cells) were used in all experiments. The medium was changed every $2-3$ days, and cell growth was assessed daily by phase-contrast microscopy. Cells were seeded at a density of $10^{5}$ cells $/ \mathrm{mm}^{2}$ in various supports, depending on the assay (see below).

\section{Cell treatment}

Stock solutions of isoC16, isoC20 and C16 (Sigma-Aldrich) were prepared at a concentration of $20 \mathrm{mM}$ in dimethylsulphoxide (DMSO) hybrimax solutions (Sigma-Aldrich). Cells were incubated with 50 or $100 \mu \mathrm{M}$ of fatty acids for $4 \mathrm{~h}$ or $24 \mathrm{~h}$ (DMSO, $1 \%$ final concentration). Control cells were incubated with $1 \%$ DMSO alone. Experiments were done at least in triplicate. 


\section{Measurement of cell viability}

Cell viability was assessed using the MTT (3-(4,5-dimethylthiazol-2-yl)-2,5-diphenyl tetrazolium bromide) assay for mitochondrial succinate dehydrogenase (SDH) activity, as we have already described. [10]

\section{Measurement of cell growth}

Cell growth was estimated through the protein content, which was determined in 24-well plates by a fluorescamine assay, as we have previously described. [10]

\section{Measurement of cell permeability}

Cell permeability was determined after staining with the phenanthrene dye propidium iodide (excitation $\lambda=540 \mathrm{~nm}$, emission $\lambda=625 \mathrm{~nm}$ ) (Sigma-Aldrich), which enters dead cells only. [11] Propidium iodide was used at a final concentration of $5 \mu \mathrm{g} / \mathrm{mL}$ on a cell suspension adjusted to $10^{6}$ cells $/ \mathrm{mL}$. Fluorescence was immediately quantified using flow cytometry in 10,000 cells on a 4-decade logarithmic scale of fluorescence on a FACScan flow cytometer (Becton Dickinson, UK) at 488-nm and 590-nm excitation and emission wavelengths, respectively.

\section{Measurement of mitochondrial transmembrane potential}

The mitochondrial transmembrane potential $\left(\Delta \psi_{\mathrm{m}}\right)$ was measured with 3,3'dihexyloxacarbocyanine iodide $\left(\operatorname{DiOC}_{6}(3)\right.$ : excitation $\lambda=484 \mathrm{~nm}$, emission $\lambda=501 \mathrm{~nm}$ ) (Molecular Probes, Inc., Eugene, OR, USA) used at a final concentration of $40 \mathrm{nM}$ in cell suspensions adjusted to $2 \times 10^{6}$ cells $/ \mathrm{mL}$. This cyanine dye, which accumulates in the mitochondrial matrix under the influence of the $\Delta \psi_{\mathrm{m}}$, was initially prepared at $1 \mathrm{mM}$ in DMSO (Sigma-Aldrich) and further diluted in distilled water to obtain a $20-\mu \mathrm{M}$ intermediate solution. After $15 \mathrm{~min}$ of incubation at $37^{\circ} \mathrm{C}, \mathrm{DiOC}_{6}(3)$ mitochondrial transmembrane potential-related fluorescence was immediately recorded by flow cytometry with a FACScan flow cytometer (Becton Dickinson). The green fluorescence was collected through a 524/44- 
$\mathrm{nm}$ band pass filter, and the fluorescent signals were measured on a 4-decade logarithmic scale. For each sample, 10,000 cells were acquired and the data were analyzed with LYSYS I software (Becton Dickinson).

\section{Evaluation of apoptotic cells}

Nuclear morphology of control and treated cells was studied using fluorescence microscopy after staining with Hoechst 33342 (Sigma-Aldrich). Apoptotic cells were essentially characterised by nuclear condensation of chromatin and/or nuclear fragmentation, as previously described. [12] Three hundred cells were examined for each sample.

\section{Measurement of inflammation}

After $24 \mathrm{~h}$ of treatment, the supernatants were harvested and stored at $-20^{\circ} \mathrm{C}$ until they were assayed. IL-1 $\beta$ was determined using ELISA kits (Raybiotech, Inc., Tebu-bio SA, Le Perrayen-Yvelines, France), according to the manufacturer's instructions. The plates were read in an ELISA-reader (Victor IV, Perkin Elmer, Courtaboeuf, France) at $450 \mathrm{~nm}$.

\section{Measurement of intracellular ROS}

Intracellular formation of ROS was detected in conjunctival cells with the fluorescent probe $2^{\prime}, 7^{\prime}$-dichlorodihydrofluorescein diacetate (DCFH-DA, Molecular Probes, Invitrogen), as we have already described. [10]

\section{Fatty acid composition of cells and mitochondria}

Mitochondria were isolated from cell cultures using a commercial kit (Pierce, Perbio, Brebières, France) according to the manufacturer's protocol. Lipids from cells and mitochondria were extracted according to the method developed by Folch et al. [13] Lipids were submitted to fatty acid methylation according to the Morrison \& Smith method (1964) and analysed using gas chromatography as previously described. [3] 


\section{Statistical analyses}

Statistical analyses were performed with the SAS software (SAS Institute, Cary, NC, USA).

ANOVA analysis was used and data were considered statistically different at $p \leq 0.05$. 


\section{RESULTS}

\section{Fatty acid incorporation in conjunctival cells}

BCFAs were not detected in conjunctival Chang cells grown under standard conditions but readily entered the cells when these were incubated with BCFAs (Table 1).

\section{Table 1 about here}

We obtained the same results in IOBA cells after addition of isoC16 and isoC20 $(23.7 \%$ and $8.4 \%$ of total fatty acids after $24 \mathrm{~h}$ incubation with $100 \mu \mathrm{M}$, respectively) (results not shown). Incubation with C16 significantly increased its endogenous pools in both Chang and IOBANHC cells (from +35 to $70 \%$ in Chang cells, Table 1). Moreover, BCFAs reached mitochondria, where they accounted for up to one-fourth to one-third of total fatty acids

(Table 2). On the contrary, incubation with C16 did not increase its incorporation into mitochondria (Table 2).

\section{Table 2 about here}

\section{Cytotoxicity of individual fatty acids}

\section{Effect of BCFAs on cell viability}

The effect of isoC16, isoC20 and $\mathrm{C} 16$ on cell viability was tested using the MTT test, whose results are presented in Table 3. The MTT test reflects mitochondrial dysfunctions by measuring the activity of various mitochondrial dehydrogenase enzymes.

\section{Table 3 about here}

There were no differences on mitochondrial SDH activity between the two cell lines $(p=$ 0.12) and between the different concentrations of branched-chain fatty acids $(p=0.16)$. However, after $4 \mathrm{~h}$ of exposure, there was significantly less SDH activity with isoC20 (45.3$69.2 \%$ of the control in Chang cells and 54.1-54.9\% in IOBA-NHC cells) and C16 (47.7$67.8 \%$ in Chang cells and 58.6-73.1\% in IOBA-NHC cells) as compared to the control. After 
$24 \mathrm{~h}$ of exposure, this activity had significantly lowered with isoC20 only (36.0-39.8\% of the control in Chang cells and 55.0-56.4\% in IOBA-NHC cells).

Fatty acids had no effect on cell growth when compared to control cells, as assessed by protein measurements on cell cultures (data not shown, $p=0.84$ ).

\section{BCFAs were not apoptotic}

BCFAs did not increase the proportion of propidium iodide-permeable cells and depolarised cells evaluated with flow cytometry ( $p=0.99$ and $p=0.80$, respectively) or the proportion of apoptotic cells evaluated by Hoechst staining $(p=0.52)$ (Table 4$)$.

\section{Table 4 about here}

\section{BCFAs did not induce IL-1 $\beta$ production}

Since BCFAs are increased in blepharitis patients with meibomian gland dysfunction [3] and meibomian gland dysfunction is associated with inflammation at the lid margins [5], we wondered whether the increase in BCFAs influenced conjunctival inflammation. To evaluate the pro-inflammatory effect of BCFA, we measured IL-1 $\beta$ production after $24 \mathrm{~h}$ of treatment. No variation in the production of IL-1 $\beta$ in Chang and IOBA-NHC cells was observed, even at high doses $(100 \mu \mathrm{M})$ of BCFAs (data not shown).

\section{BCFAs did not affect ROS production}

ROS production was not modified by BCFAs, as shown in Table $5(p=0.52)$.

\section{Table 5 about here}

\section{DISCUSSION}

The lacrimal film provides the interface between the eye and the outer environment. It is composed of an aqueous layer $(7-10 \mu \mathrm{m}$ thick) covered by the thin tear film-lipid layer (TFLL, $100 \mathrm{~nm}$ thickness) at the external side. [14] The TFLL is secreted by the meibomian 
glands and is highly structured. [15] Its main functions are to delay evaporation, maintain a smooth optical surface and provide a barrier against micro-organisms or skin sebum. [5] Significant alterations of the TFLL can lead to a higher rate of tear evaporation, which predisposes to chronic blepharitis and dry eye. [16] Our previous study showed that blepharitis patients with MGD displayed an increase in BCFAs associated with a sharp decrease in saturated fatty acids. [3] Until now, the reason for the increase in BCFAs has remained unknown. Since BCFAs exhibit a lower melting point than the corresponding straight-chain fatty acids, the specific functions of the increase in BCFAs may be enhancing lipid fluidity and providing greater resistance to environmental (evaporation) and biological stresses. [17] The increase in BCFAs may therefore be a beneficial adaptive response of the body counterbalancing the lack of tears by spreading the tear film on the ocular surface. Alternatively, the increase in BCFAs may also have detrimental consequences on conjunctival cells by increasing inflammation and apoptosis and then participating in the vicious circle of blepharitis. Indeed, BCFAs in tears may be toxic for the conjunctiva since conjunctival cells are in permanent contact with lacrimal film and their toxic effects have already been shown in other tissues. [6, 7]

Our results showed no cytotoxic effects of the two BCFAs tested - isoC16 and isoC20 contrary to treatment with benzalkonium chloride $(0.02 \%)$, which induced mitochondrial toxicity and apoptosis [18]:

1. BCFAs were not observed to have an effect on morphological aspects of the cells stemming from the concentration tested $(50 \mu \mathrm{M}$ or $100 \mu \mathrm{M})$, the duration of treatment ( $4 \mathrm{~h}$ or $24 \mathrm{~h}$ ) or the type of cell line (Chang or IOBA-NHC) (results not shown).

2. BCFAs were not toxic to the plasma membrane, as shown by the nonpermeability of the conjunctival cells to propidium iodide, or to the nucleus, as shown by Hoechst staining. 
3. BCFAs did not affect mitochondrial depolarisation. However, only isoC20 induced a significant decrease in mitochondrial SDH activity after $4 \mathrm{~h}$ of treatment as well as after $24 \mathrm{~h}$ in Chang cells and IOBA-NHC cells. This change did not result from a decrease in the number of cells, as shown by the same protein content. It may be attributable to an alteration in the ability of mitochondria to undergo metabolic changes related to the substantial incorporation of isoC20 in mitochondrial membranes. Indeed, isoC20 accounted for $24.4 \%$ of the total fatty acids in mitochondria. This may modify membrane fluidity, leading to changes in SDH activity. IsoC16 was also incorporated into mitochondria in large quantities (36.1\% of total fatty acids). However, since it has fewer carbon atoms, it may not increase fluidity as much as isoC20. Moreover, changes in membrane fluidity may regulate certain cellular reactions involving membrane-associated enzymes. For example, an increase in membrane fluidity caused by the incorporation of polyunsaturated fatty acids into membrane increased the activation energy (Ea) of mitochondrial enzymes. [19] Hence, isoC20 may have a direct influence on the SDH active site, contrary to isoC16. We also observed a significant decrease in mitochondrial SDH activity when incubated with $\mathrm{C} 16$ for $4 \mathrm{~h}$. The toxicity of saturated fatty acids $(70-1000 \mu \mathrm{M})$ has already been observed in other cell types such as endothelial cell monolayers [20] and skeletal muscle cells. [21] The absence of toxicity after $24 \mathrm{~h}$ of exposure to C16 means that conjunctival cells were able to detoxify $\mathrm{C} 16$, probably by oxidation and without producing toxic metabolites.

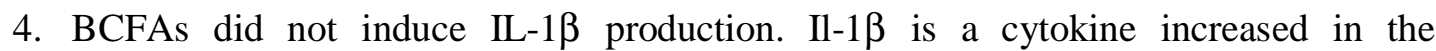
conjunctival epithelium during dry eye, like other cytokines such as IL- 8 and TNF- $\alpha$. $[22,23]$ Hence BCFAs were not pro-inflammatory in conjunctival cells. 
5. BCFA did not induce ROS production. The production of ROS is a highly controlled process. Excessive ROS production has deleterious effects by initiating lipid peroxidation.

This lack of a toxic effect did not result from these fatty acids not being incorporated. BCFAs were incorporated into the cells' total lipids, between 2 and $7.9 \%$ of total fatty acids after $4 \mathrm{~h}$ of treatment and 4.5 and $9.6 \%$ after $24 \mathrm{~h}$. We studied Chang cells, which are human immortalised cells. [24] Despite their similarity with in situ conjunctival epithelium (presence of tight junctions, microvillosities, mucin secretion) and their widespread use in the study of the expression of inflammation-related markers or apoptosis [25], they may behave differently, especially toward toxic molecules, since these cells have HeLa-marker chromosomes. To lessen the impact of the use of the Chang cell line, we verified all the results on IOBA-NHC cells, a nontransfected, spontaneously immortalised epithelial cell line from normal human conjunctiva. These cells retain morphologic and functional conjunctival epithelial characteristics in vitro. [26] We found the same results in IOBA-NHC cells as in Chang cells: absence of BCFA and C16 toxicity (viability, apoptosis, inflammation) and incorporation of these fatty acids into cell lipids. This confirms that Chang cells and IOBANHC cells are comparable for the in vitro toxicological studies, as previously shown. [9] The increase in BCFAs in the tears of patients with meibomian gland dysfunction had no deleterious effect on conjunctival cells and may instead reflect an adaptive response of the body attempting to increase tear film stability. Indeed, in MGD, meibum is thicker and loses its physical properties required to stabilise the lacrimal film. IsoC20 may have a prominent role, as suggested by our previous study showing a partial, significant restoration of the isoC20 content after minocycline treatment associated with lid hygiene [4], suggesting that the increase in isoC20 may be an adaptive response of the meibomian gland to local changes such as MGD. 


\section{REFERENCES}

1 Edwards RS. Ophthalmic emergencies in a district general hospital casualty department. Br J Ophthalmol. 1987;71:938-42.

2 Miljanovic B, Dana R, Sullivan DA, et al. Impact of dry eye syndrome on vision-related quality of life. American journal of ophthalmology. 2007;143:409-15.

3 Joffre C, Souchier M, Gregoire S, et al. Differences in meibomian fatty acid composition in patients with meibomian gland dysfunction and aqueous-deficient dry eye. Br J Ophthalmol. 2008;92:116-9.

4 Souchier M, Joffre C, Gregoire S, et al. Changes in meibomian fatty acids and clinical signs in patients with meibomian gland dysfunction after minocycline treatment. Br J Ophthalmol. 2008;92:819-22.

5 Foulks GN, Bron AJ. Meibomian gland dysfunction: a clinical scheme for description, diagnosis, classification, and grading. Ocul Surf. 2003;1:107-26.

6 Idel S, Ellinghaus P, Wolfrum C, et al. Branched chain fatty acids induce nitric oxide-dependent apoptosis in vascular smooth muscle cells. J Biol Chem. 2002;277:49319-25.

7 Schonfeld P, Kahlert S, Reiser G. A study of the cytotoxicity of branched-chain phytanic acid with mitochondria and rat brain astrocytes. Exp Gerontol. 2006;41:688-96.

8 Singh V, Hattangady D, Giotis E, et al. Insertional inactivation of branched-chain alpha-keto acid dehydrogenase in Staphylococcus aureus leads to decreased branched-chain membrane fatty acids content and increased susceptibility to certain stresses. Appl Environ Microbiol. 2008;74:5882-90.

9 Brasnu E, Brignole-Baudouin F, Riancho L, et al. Comparative study on the cytotoxic effects of benzalkonium chloride on the Wong-Kilbourne derivative of Chang conjunctival and IOBA-NHC cell lines. Mol Vis. 2008;14:394-402.

10 Joffre C, Leclere L, Buteau B, et al. Oxysterols induced inflammation and oxidation in primary porcine retinal pigment epithelial cells. Current eye research. 2007;32:271-80.

11 Yeh CJ, Hsi BL, Faulk WP. Propidium iodide as a nuclear marker in immunofluorescence. II. Use with cellular identification and viability studies. J Immunol Methods. 1981;43:269-75.

12 Lizard G, Fournel S, Genestier L, et al. Kinetics of plasma membrane and mitochondrial alterations in cells undergoing apoptosis. Cytometry. 1995;21:275-83.

13 Folch J, Lees M, Sloane-Stanley G. A simple method for the isolation and purification of total lipids from animal tissues. J. Biol. Chem. 1957;226:497-509.

14 Tiffany JM. Physiological functions of the meibomian glands. Prog Retin Eye Res. 1995;14:47-74.

15 Bron AJ, Tiffany JM, Gouveia SM, et al. Functional aspects of the tear film lipid layer. Experimental eye research. 2004;78:347-60.

16 Craig JP, Tomlinson A. Importance of the lipid layer in human tear film stability and evaporation. Optom Vis Sci. 1997;74:8-13.

17 Tiffany JM. Refractive index of meibomian and other lipids. Current eye research. 1986;5:887-9. 
18 Buron N, Micheau O, Cathelin S, et al. Differential mechanisms of conjunctival cell death induction by ultraviolet irradiation and benzalkonium chloride. Invest Ophthalmol Vis Sci. 2006;47:4221-30.

19 McMurchie EJ, Raison JK. Membrane lipid fluidity and its effect on the activation energy of membraneassociated enzymes. Biochimica et biophysica acta. 1979;554:364-74.

20 Zhang CL, Lyngmo V, Nordoy A. The effects of saturated fatty acids on endothelial cells. Thrombosis research. 1992;65:65-75.

21 Rachek LI, Musiyenko SI, LeDoux SP, et al. Palmitate induced mitochondrial deoxyribonucleic acid damage and apoptosis in 16 rat skeletal muscle cells. Endocrinology. 2007;148:293-9.

22 Pflugfelder SC, Jones D, Ji Z, et al. Altered cytokine balance in the tear fluid and conjunctiva of patients with Sjogren's syndrome keratoconjunctivitis sicca. Current eye research. 1999;19:201-11.

23 Viau S, Maire MA, Pasquis B, et al. Time course of ocular surface and lacrimal gland changes in a new scopolamine-induced dry eye model. Graefes Arch Clin Exp Ophthalmol. 2008;246:857-67.

24 Lavappa KS, Macy ML, Shannon JE. Examination of ATCC stocks for HeLa marker chromosomes in human cell lines. Nature. 1976;259:211-3.

25 Guenoun JM, Baudouin C, Rat P, et al. In vitro comparison of cytoprotective and antioxidative effects of latanoprost, travoprost, and bimatoprost on conjunctiva-derived epithelial cells. Invest Ophthalmol Vis Sci. 2005;46:4594-9.

26 Diebold Y, Calonge M, Enriquez de Salamanca A, et al. Characterization of a spontaneously immortalized cell line (IOBA-NHC) from normal human conjunctiva. Invest Ophthalmol Vis Sci. 2003;44:4263-74. 
Table 1: Branched-chain fatty acid content in total lipids of Chang cells after $4 \mathrm{~h}$ and $24 \mathrm{~h}$ of exposure (\% of total fatty acids).

\begin{tabular}{|c|c|c|c|}
\hline & \multicolumn{3}{|c|}{$4 \mathrm{~h}$} \\
\hline & $\begin{array}{c}\text { Control } \\
n=3\end{array}$ & $\begin{array}{c}50 \mu \mathrm{M} \\
n=3\end{array}$ & $\begin{array}{c}100 \mu M \\
n=3\end{array}$ \\
\hline C16 & $14.9 \pm 0.91$ & $20.2 \pm 0.42$ & $23.6 \pm 1.21$ \\
\hline isoC16 & ND & $2.0 \pm 0.14$ & $4.9 \pm 1.14$ \\
\hline \multirow[t]{3}{*}{ isoC20 } & ND & $5.9 \pm 1.52$ & $7.9 \pm 2.91$ \\
\hline & \multicolumn{3}{|c|}{$24 h$} \\
\hline & $\begin{array}{c}\text { Control } \\
n=3\end{array}$ & $\begin{array}{c}50 \mu \mathrm{M} \\
n=3\end{array}$ & $\begin{array}{c}100 \mu M \\
n=3\end{array}$ \\
\hline C16 & $14.6 \pm 0.57$ & $19.9 \pm 1.08$ & $24.5 \pm 0.84$ \\
\hline isoC16 & ND & $4.5 \pm 0.01$ & $9.6 \pm 3.00$ \\
\hline isoC20 & ND & $6.9 \pm 1.35$ & $8.1 \pm 3.64$ \\
\hline
\end{tabular}

Data are means \pm SEM and represent three independent experiments.

ND: not detected. 
Table 2: Branched-chain fatty acid incorporation in mitochondria of Chang cells after $24 \mathrm{~h}$ of exposure $(100 \mu \mathrm{M})(\%$ of total fatty acids).

\begin{tabular}{|l|c|c|}
\hline & Control & $\mathbf{1 0 0} \boldsymbol{\mu M}$ \\
\hline C16 & $10.3 \pm 1.15$ & $11.8 \pm 1.13$ \\
\hline isoC16 & ND & $36.1 \pm 2.26$ \\
\hline & & \\
\hline isoC20 & ND & $24.4 \pm 2.94$ \\
\hline
\end{tabular}

Data are means \pm SEM and represent three independent experiments. ND: not detected. 
Table 3: Cell viability in Chang and IOBA-NHC cells after incubation with branched-chain fatty acids, as assessed by measuring SDH activity with the MTT test. Values are expressed as the percentage of control conditions (without incubation with any fatty acids).

\begin{tabular}{|c|c|c|c|c|c|}
\hline \multicolumn{6}{|c|}{$4 h$} \\
\hline & & \multicolumn{2}{|c|}{ Chang cells } & \multicolumn{2}{|c|}{ IOBA-NHC cells } \\
\hline & Control & $50 \mu \mathrm{M}$ & $100 \mu \mathrm{M}$ & $50 \mu \mathrm{M}$ & $100 \mu \mathrm{M}$ \\
\hline C16 & $100^{\mathrm{a}}$ & $67.8 \pm 7.10^{b}$ & $47.7 \pm 4.59^{c}$ & $73.1 \pm 8.50^{b}$ & $58.6 \pm 7.04^{b c}$ \\
\hline IsoC16 & 100 & $101.0 \pm 3.77$ & $99.3 \pm 2.95$ & $104.9 \pm 4.22$ & $101.7 \pm 2.84$ \\
\hline IsoC20 & $100^{\mathrm{a}}$ & $45.3 \pm 3.87^{c}$ & $69.2 \pm 2.69^{b}$ & $54.1 \pm 5.66^{b c}$ & $54.9 \pm 7.75^{b c}$ \\
\hline \multicolumn{6}{|c|}{$24 h$} \\
\hline & & \multicolumn{2}{|c|}{ Chang cells } & \multicolumn{2}{|c|}{ IOBA-NHC cells } \\
\hline & Control & $50 \mu \mathrm{M}$ & $100 \mu \mathrm{M}$ & $50 \mu \mathrm{M}$ & $100 \mu \mathrm{M}$ \\
\hline C16 & 100 & $89.4 \pm 12.57$ & $80.5 \pm 11.13$ & $83.6 \pm 4.56$ & $68.4 \pm 5.67$ \\
\hline IsoC16 & 100 & $95.9 \pm 7.16$ & $99.0 \pm 10.38$ & $109.3 \pm 6.09$ & $103.1 \pm 2.05$ \\
\hline IsoC20 & $100^{\mathrm{a}}$ & $39.8 \pm 2.45^{b}$ & $36.0 \pm 1.82^{b}$ & $56.4 \pm 2.95^{b}$ & $55.0 \pm 3.64^{b}$ \\
\hline
\end{tabular}

Data are means \pm SEM. For the Chang cells, $n=3-5$ and for the IOBA-NHC cells $n=3$. On the same row, the means with different superscripts ( $\mathrm{a}, \mathrm{b}$ or $\mathrm{c}$ ) differ significantly $(p \leq 0.05)$. 
Table 4: Evaluation of the apoptotic effect of branched-chain fatty acids $(100 \mu \mathrm{M})$ incubated for $24 \mathrm{~h}$ in Chang and IOBA-NHC cells.

\begin{tabular}{|l|c|c|c|c|c|c|}
\hline \multirow{2}{*}{} & \multicolumn{2}{|c|}{$\begin{array}{c}\text { \% of cells permeable to } \\
\text { propidium iodide }\end{array}$} & \multicolumn{2}{c|}{ \% of depolarised cells } & \multicolumn{2}{c|}{ \% of apoptotic cells } \\
& Chang & IOBA-NHC & Chang & IOBA-NHC & Chang & IOBA-NHC \\
\hline Control & $5.9 \pm 2.34$ & $6.3 \pm 2.85$ & $11.8 \pm 2.85$ & $10.0 \pm 1.00$ & $7.3 \pm 4.07$ & $3.5 \pm 0.50$ \\
\hline C16 & $7.4 \pm 4.12$ & $7.7 \pm 0.33$ & $12.6 \pm 4.84$ & $7.3 \pm 0.66$ & $10.7 \pm 6.78$ & $2.7 \pm 0.60$ \\
\hline IsoC16 & $6.8 \pm 3.93$ & $5.0 \pm 0.00$ & $11.4 \pm 4.42$ & $10.0 \pm 2.00$ & $9.4 \pm 6.75$ & $2.2 \pm 0.73$ \\
\hline IsoC20 & $6.5 \pm 3.44$ & $8.3 \pm 0.33$ & $10.8 \pm 5.25$ & $5.7 \pm 0.33$ & $12.0 \pm 5.51$ & $3.0 \pm 0.29$ \\
\hline
\end{tabular}

Percent of propidium iodide-permeable cells was determined by flow cytometry after staining with propidium iodide. Percent of depolarised cells corresponding to cells characterised by a loss of mitochondrial transmembrane potential were determined using flow cytometry after staining with DiOCC $_{6}(3)$. Percent of apoptotic cells (with fragmented and/or condensed nuclei) was determined after staining with Hoechst 33342. Data are means \pm SEM and represent three independent experiments. 
Table 5: Intracellular ROS detection in Chang and IOBA-NHC cells after branched-chain fatty acid treatment (ratio to control).

\begin{tabular}{|c|c|c|c|c|c|}
\hline \multicolumn{6}{|c|}{$4 h$} \\
\hline & & \multicolumn{2}{|c|}{ Chang cells } & \multicolumn{2}{|c|}{ IOBA-NHC cells } \\
\hline & Control & $50 \mu \mathrm{M}$ & $100 \mu \mathrm{M}$ & $50 \mu \mathrm{M}$ & $100 \mu \mathrm{M}$ \\
\hline C16 & 100 & $76.9 \pm 10.26$ & $83.2 \pm 5.99$ & $93.1 \pm 10.22$ & $101.5 \pm 10.92$ \\
\hline IsoC16 & 100 & $100.6 \pm 2.77$ & $86.9 \pm 5.53$ & $90.7 \pm 10.69$ & $92.1 \pm 15.51$ \\
\hline IsoC20 & 100 & $94.6 \pm 6.24$ & $94.1 \pm 5.73$ & $92.2 \pm 14.75$ & $90.5 \pm 12.68$ \\
\hline \multicolumn{6}{|c|}{$24 h$} \\
\hline & & \multicolumn{2}{|c|}{ Chang cells } & \multicolumn{2}{|c|}{ IOBA-NHC cells } \\
\hline & Control & $50 \mu \mathrm{M}$ & $100 \mu \mathrm{M}$ & $50 \mu \mathrm{M}$ & $100 \mu \mathrm{M}$ \\
\hline C16 & $100^{a b}$ & $85.5 \pm 4.85^{b}$ & $94.2 \pm 7.22^{\mathrm{ab}}$ & $116.3 \pm 10.43^{a}$ & $104.8 \pm 9.47^{\mathrm{ab}}$ \\
\hline IsoC16 & 100 & $88.4 \pm 5.44$ & $91.5 \pm 6.88$ & $103.8 \pm 3.61$ & $108.8 \pm 8.59$ \\
\hline IsoC20 & 100 & $99.4 \pm 12.93$ & $104.6 \pm 9.96$ & $102.0 \pm 8.82$ & $117.2 \pm 8.17$ \\
\hline
\end{tabular}

Intracellular formation of ROS was detected in conjunctival cells with the fluorescent probe $2^{\prime}, 7^{\prime}$ dichlorodihydrofluorescein diacetate (DCFH-DA). The DCF fluorescence resulting from the oxidation of DCFH-DA was measured with a fluorescence multi-well plate reader. Data are means \pm SEM. For the Chang cells, $n=3-5$ and for the IOBA-NHC cells $n=3$. On the same row, the means with different superscripts $(\mathrm{a}, \mathrm{b}$ or $\mathrm{c})$ differ significantly $(p \leq 0.05)$. 